\title{
The Influence of Peer Education on Sadari (Self-Breast Examination) Behaviour in Preventing Breast Cancer For Woman of Childbearing Age in South Lampung, Indonesia
}

\author{
Dewi Yuliana, Radella Hervidea \\ Nursing Study, Health Faculty, \\ Mitra Indonesia University \\ Email: \\ Dewiyuliana429@yahoo.co.id
}

Received : October 5, 2020

Accepted : November 29, 2020

Published : November 30, 2020

\begin{abstract}
Breast cancer is a malignant tumor which developed in breast cells. According to $\mathrm{WHO}$, an effective method to improve earlier breast cancer detection is by self-breast examination and this is proven to reduce breast cancer mortality rate since 1990 . The objective of this research was to find out the influence of peer education on SADARI (self-breast examination) behaviour in preventing breast cancer for woman of childbearing age in South Lampung, Indonesia. This was a quantitative study by using pre-experimental approach and one group pretest and posttest design. The samples were 32 respondents who were taken by using random sampling. Data were obtained through questionnaires and analyzed by using statistic test with t-dependent test (paired t-test). The result shows that there is an influence of peer education on SADARI behaviour in preventing breast cancer for woman of childbearing age in South Lampung, Indonesia with p-value 0.000. SADARI behavior can be done to women as a self-examination, especially women of childbearing age to prevent breast cancer.
\end{abstract}

Keywords: Peer education, SADARI, breast cancer

Copyright (C) 2020 IIK STRADA Indonesia All right reserved.

This is an open-acces article distributed under the terms of the Creative Commons Attribution-ShareAlike 4.0 International License.

\section{INTRODUCTION}

Cancer is the second cause that contributes $13 \%$ of death from $22 \%$ of death from main noncontagious diseases after heart and vessel blood diseases. One kind of cancers that often attack especially women is breast cancer. Breast cancer is usually found in 40-50 year-old women, but recently it is found in the age of 18 years (Society, 2011).

Based on WHO data in 2013, the incidence of cancer disease had increased at around 12.7 million cases in 2018, meanwhile in 2012 it reached 14,1 million cases. Based on data from the Lampung Provincial Health Office in 2015, the breast cancer disease in South Lampung regency is second highest number after Bandar Lampung (Lampung Province Health Profile, 2015). The breast cancer case at Karang Anyar village is noted as the highest case in South Lampung regency (South Lampung Health Office, 2017).

It is estimated that in 2030 the incidence of cancer could reach around 26 million cases or the patient can be estimated that around 17 million of them could die due to the risk of this cancer. Especially for poor countries and developing countries, the incidence of cancer can occur more quickly (Ministry of Health, 2014). Meanwhile, according to World Health Organization (WHO), in 2018 it is estimated that cancer sufferers that mostly occur in Indonesia are breast cancer, with a total 
of 58,256 cases, around $16.7 \%$ of the total previous results, namely 348,809 cases of breast cancer (Ministry of Health, 2018).

According to Romauli (2011) the cause of breast cancer is not certain, but there are several risk factors for breast cancer, including internal and external factors. Internal factors include family history, the influence of the hormone estrogen excess, menstruation too early, not married, not breastfeeding, and late exposure. Meanwhile, external factors are poor diet, smoking, drinking alcohol, and pollution. Another cause of breast cancer is due to limited public knowledge about the dangers of cancer, early signs of cancer, risk factors for cancer, how to deal with it properly and familiarize oneself with a healthy lifestyle.

Most breast cancer sufferers are usually found when it is at an advanced stage. Therefore the recovery process is very difficult to do. Meanwhile, knowing breast cancer early is possible and can be done by oneself at home. The more women carry out breast self-exams, the more they can understand and find abnormalities that occur in their breasts more quickly (Savitri, 2015).

Actions that need to be taken to someone who has risk factors for breast cancer through health promotion how to do BSE (Self-Breast Examination) because about $90 \%$ of a breast tumor can be detected by women by doing early detection, namely BSE (Shadine, 2012). Women of reproductive age are women whose reproductive organs function properly between the ages of 20-45 years. Women who are at this age are included in the productive age section of women of reproductive age who have reproductive organs that are still functioning properly (Ministry of Health, 2019). Most of the women in fertile age have not done BSE (Breast Self Examination) due to the lack of public knowledge about breast cancer and early detection with BSE. They think that BSE activities do not need to be carried out or implemented for people who are not sick or healthy.

Good knowledge can be received with good delivery media. This can lead to correct understanding and knowledge of BSE. This knowledge is the most important thing and can lead to healthy behavior. This knowledge is the behavior of early breast cancer detection. Education can be explained as an effort to be able to carry out learning and educational activities as well as assistance for individuals or community groups. Education by peer groups is a process of communication, information and education (IEC) carried out by and for peers. Peer group education is an effort to change health behavior through peer groups (Romlah, 2001). The results of the research by (Aisah et al., 2010)prove that peer education is effective in influencing behavior change which includes knowledge, attitudes and skills.

Knowledge is an important thing in order to shape the behavior of a person's actions (behavior). The attitude to be able to act according to someone's situation, by considering whether something is good or right, and when it is a good choice or not, is an emotional state that can happen to someone. Attitude is a balance in terms of feelings, thought, and a person's tendency to act on an object in the surrounding. (Azwar, 2011).

Based on the background described above and the importance of breast cancer prevention efforts, this study aims to observe on the effect of peer education on BSE behavior (Breast Self Examination) in breast cancer prevention in fertile aged women in South Lampung, Indonesia.

\section{MATERIAL AND METHOD}

This study used a pre-experimental design method. The research used One Group Pre Test Post Test design. The population in this study were 158 people. Samples taken were 32 people according to the inclusion and exclusion criteria using random sampling technique. This research was conducted from $10^{\text {th }}-18^{\text {th }}$ June 2020. Data was gathered through questionnaires by using questionnaire sheets and observation sheets.

In this study, univariate analysis was used to determine the frequency distribution of each variable and a bivariate analysis was performed to determine the relationship between variables. Bivariate analysis used the t-dependent test with a significance level of $=0.05$. Data is presented by using frequency distribution tables and t-paired/related tables.

\section{RESULT}

Based on table 1, it was found that based on age, the most number of the respondents are 26-30 years old, as many as 10 respondents $(31.25 \%)$. Based on the education level, most of the respondents were 
high school /vocational graduates, as many as 16 respondents (50\%). While based on occupation, 19 respondents (59.37\%) were housewives (IRT).

Table 1. The Frequency Distribution of Age, Education, Occupation

\begin{tabular}{lcc}
\hline Variables & N $(=\mathbf{1 0 0})$ & $\mathbf{\%}$ \\
\hline Age & 5 & \\
$20-25$ & 10 & 15,62 \\
$26-30$ & 6 & 31,25 \\
$31-35$ & 8 & 18,75 \\
$36-40$ & 3 & 25 \\
$41-45$ & & 9,37 \\
Education & 1 & \\
$\quad$ College & 16 & 3,12 \\
$\quad$ Senior/Vocational High School & 7 & 50 \\
$\quad$ Junior High School & 8 & 21,87 \\
Elementary School & & 25 \\
Occupation & 1 & \\
$\quad$ Government Employees & 2 & 3,12 \\
$\quad$ Temporary Employees & 10 & 6,25 \\
Entrepreneur & 19 & 31,25 \\
Housewives & & 59,37 \\
\hline Source Primary Data, & &
\end{tabular}

Source: Primary Data, 2020

Table 2. The Result of Statistical Test on The Effect of Knowledge on Breast Cancer Prevention for Woman of Childbearing Age

\begin{tabular}{c|c|c|c|c|c}
\hline Variables & Mean & SD & SE & $\boldsymbol{p}$ value & $\mathbf{N}$ \\
\hline $\begin{array}{c}\text { Before the } \\
\text { Treatment }\end{array}$ & 2,72 & 2,831 & 0,500 & 0,000 & 32 \\
$\begin{array}{c}\text { After the } \\
\text { Treatment }\end{array}$ & 9,97 & 0,177 & 0,031 & & \\
\hline
\end{tabular}

Source: Primary Data, 2020

Based on table 2, it was known that the average value of the respondents' knowledge about breast cancer before health education was given was 2.72 with a standard deviation of 2.831 . The value measurement that was carried out after health education was given was 9.97 with a standard deviation of 0.177. It can be seen that the mean difference between before the treatment and after the treatment was 7.25 with a standard deviation of 2.654. The statistical test results obtained a p-value of 0.000 ( $\alpha$ value $<0.05$ ). Therefore, it can be concluded that there is influence of knowledge on breast cancer prevention before and after peer education was given to women of childbearing age in South Lampung, Indonesia.

Table 3. The Result of Statistical Test on The Effect of Attitude on Breast Cancer Prevention for Woman of Childbearing Age

\begin{tabular}{c|c|c|c|c|c}
\hline Variabel & Mean & SD & SE & p-value & $\mathbf{N}$ \\
\hline $\begin{array}{c}\text { Before the } \\
\text { Treatment }\end{array}$ & 32,50 & 14,199 & 2,520 & 0,000 & 32 \\
$\begin{array}{c}\text { After the } \\
\text { Treatment }\end{array}$ & 67,27 & 4,725 & 0,835 & & \\
\hline
\end{tabular}

Source: Primary Data, 2020

Based on table 3, the data showed that the average value of the respondent's attitude about breast cancer prevention before health education was given was 32.50 with a standard deviation of 
14.199. The measurement of value that was carried out after health education was given was 67.27 with a standard deviation of 4.725 . It can be seen that the mean difference between before and after the peer education treatment was 34.77 with a standard deviation of 9.474. The statistical test results obtained a p-value of 0.000 ( $\alpha$ value $<0.05)$. Therefore, it can be seen that there is influence of attitude on breast cancer prevention before and after peer education was given to women of childbearing age in South Lampung, Indonesia.

\section{DISCUSSION}

Based on the results of the analysis obtained in this study, the average knowledge of women of reproductive age at the time of the pre test was 2.72 with a standard deviation of 2.831 . At the time of the post test, the average knowledge of women of childbearing age was 9.97 with a standard deviation of 0.177. From this description, it can be seen that there is a difference in the value of the mean between the pre test and the post test, which is 7.25. The results of the paired t-test showed that a significant value (2-tailed) was 0.000 . This value is smaller than the $\alpha$ (alpha) value of 0.05 . Thus, it can be concluded that there is a significant influence between the knowledge of women of childbearing age before the treatment is given and after the treatment is given.

The results of this study are in line with Andita's (2016) study entitled The Effect of BSE Health Education with Slide Media and Artificial Objects on Changes in WUS Knowledge, the results showed that there was a significant effect with $p$-value $=0,000$.

Another study by (Hutapea, 2017) entitled The Effect of Self-Breast Examination (BSE) on Students' Knowledge and Ability in Early Breast Cancer Detection Efforts at Swakarya High School showed that there was a significant effect after health education about BSE was given with p-value = 0,000 .

This is supported by a theory which states that health education is an attempt to convey or provide information to the public as well as groups and individuals. Due to this information, it is hoped that the community, groups and even individuals can grasp a better understanding and knowledge about health. Health education is aimed to foster a view and awareness of the community on healthy living (Notoadmodjo, 2010). To be exact, health education is a learning process in providing knowledge to the public so that people understand the importance of maintaining a healthy body. Education can be provided by using the Peer Education method. Peer Education can be used to change individual behavior to be positive by modifying a person's knowledge or behavior, and can influence a change at the group or community level by modifying norms (Hayati, 2009).

The results of statistical tests to determine the effect of breast cancer prevention attitudes before and after peer education is given shows that the average value of respondents' attitudes about breast cancer prevention (BSE) before health education is given is 32.50 with a standard deviation of 14.199. The measurement of the value that was carried out after health education was given was 67.27 with a standard deviation of 4.725 . It can be seen that the mean difference between the attitude before and after health education was given was 34.77 with a standard deviation of 9.474. The results obtained a p-value of 0.000 ( $\alpha$ value $<0.05)$. From these results, it is fair to say that there is an effect of attitudes about breast cancer prevention before and after peer education is given to women of reproductive age.

Another research conducted by (Purnani \& Binti, 2018) regarding the effectiveness of health education using Peer Group Education method with demonstration method on BSE skills found that Peer group education method is more effective than demonstration method as a learning method, especially for psychomotoric learning with $\mathrm{p}$-value $=0,000$.

Another study conducted by (Sari, 2017) on the effect of breast cancer counseling on BSE attitudes of female adolescents at Al Munawwir Krapyak Bantul Islamic Boarding School, found that there was a significant influence between breast cancer counseling on BSE attitudes with p-value = 0,000 .

According to the theory of Azwar (2011), the media has a big influence in shaping a person's judgment and individual beliefs. Media that provides suggestive messages can direct a person's opinion. The existence of new information obtained through the media provides a new cognitive foundation for the formation of attitudes towards it. If the message is strong enough, the message or information will provide an affective basis in assessing something so that a certain attitude is formed. In addition, there is one important factor that can also influence attitudes, which is the provider himself. The provider who is able to master the material and deliver the material well will give more 
impact to the listeners. This is in accordance with the theory presented by Notoatmodjo (2012) that a successful lecture is if the lecture itself masters what material will be discussed, for that the lecturer must prepare himself by comprehending the material with good systematic.

\section{CONCLUSION}

This study shows that there is an effect of peer education on BSE behavior (Breast Self Examination) in breast cancer prevention in childbearing aged women in South Lampung, Indonesia with a p-value of $0.000<\alpha 0.05$. Based on the results of this study, it can be suggested that women of childbearing age should be given health information about what to do to prevent breast cancer by using various available health information media. Women of childbearing age should be able to practice regular breast self-examination in their daily life so that they can detect abnormalities in the breast early and prevent breast cancer.

\section{REFERENCES}

Aisah, S., Sahar, J., \& Hastono, sutanto priyo. (2010). Pengaruh Edukasi Kelompok Sebaya terhadap Perubahan Perilaku Pencegahan Anemia Gizi Besi pada Wanita Usia Subur di Kota Semarang.

Prosiding Seminar Nasional, 119-127. http://jurnal.unimus.ac.id

Azwar, Saifuddin, 2012. Sikap Manusia Teori dan Pengukurannya. Yogyakarta: Pustaka Pelajar Hutapea, M. (2017). The Effect of Implementation of Own Breast Examination on Knowledge and Skills Ability in The Early Detection of Breast Cancer Breast Cancer Detection in 2017. Jurnal Riset Hesti Medan, 2(2), 105-116.

Notoatmodjo (2), 2012. Promosi Kesehatan dan Perilaku Kesehatan. Jakarta : Rineka Cipta Purnani, W. T., \& Binti, Q. (2018). Efektivitas Pendidikan Kesehatan Metode Peer Group Education Dengan Metode Demonstrasi Terhadap Keterampilan Sadari. IEEE International Conference on Acoustics, Speech, and Signal Processing (ICASSP) 2017, 41(2), 84-93.

Romauli, S. (2011). Buku Ajar Kebidanan Konsep Dasar Asuhan Kehamilan. Yogyakarta: Nuha Medika.

Romlah, T. 2001. Teori dan Praktek Bimbingan Kelompok. Malang: UN.

Savitri, Astrid, dkk. (2015). Kupas Tuntas Kanker Payudara, Leher Rahim, dan Rahim. Yogyakarta : Pustaka Baru Press

Sari, W. C. (2017). Pengaruh penyuluhan kanker payudara terhadap sikap sadari pada remaja putri di pondok pesantren al munawwir krapyak bantul yogyakarta. Naskah Publikasi.

Shadine, Mahnnad, 2012. Penyakit Wanita. Yogyakarta : Citra Pustaka.

Society, A. C. (2011). Breast Cancer 2009-2010. Atlanta: American Cancer Society, Inc. 